\title{
The Relationship between Selective Staffing, Work Environment and Employee Turnover in the Malaysian Hotel Industry
}

\author{
Md Murad Miah \\ MSc in Business Management \\ Faculty of Business and Management \\ Universiti Teknologi MARA (UiTM) \\ 40450 Shah Alam, Selangor. \\ Dr Nor IntanAdhaHafit \\ Senior Lecturer, Faculty of Business Management \\ Universiti Teknologi MARA (UiTM) 40450 Shah Alam \\ Selangor
}

\begin{abstract}
The paper focuses on the relationship between selective staffing, work environment and employee turnover. This study also found the components that are related to employee turnover. In any case, this paper centres on the hotel industry of Malaysia where the highest rate of employee turnover compares to other industries in Malaysia. Besides, this study found that the Malaysian hotel industry confronting staffing issues, and factors of the work environment plays a critical part in employee turnover intention. In any case, there is a few impediments also plays in this study particularly objective has not tested and focused on the development of a conceptual framework, thus, further research should focus on testing the objectives and focusing on other industry except hotel industry.
\end{abstract}

Keywords: Selective Staffing; Employee turnover; Work environment; Hotel Industry; Malaysia.

\section{Introduction}

Employee turnover intention is the behavioural exhibit of an individual who wants to withdraw from an organization and is an effective indicator of actual turnover (Xiong \& Wen, 2020). As demonstrated by Al Mamun and Hasan, (2017) employee turnover imperils organizational execution and efficiency on account of its related to the loss of noteworthy corporate resources and company assets. Hence, the noteworthiness of HR is amazingly significant for the hospitality industry especially the hotel industry since it depends upon service quality, customer satisfaction and loyalty, competitiveness, and definitive execution (Betts, 2020). Regardless, managing employees effectively is likely the greatest challenge looked by hotel managers nowadays (Haynes \& Egan, 2020).The challenges of managing human resources have been broadly talked about within the hospitality management (Naik \&Kanade, 2019; Tuan, 2018; Kusluvan et al., 2010)especially concentrating on employee turnover (Santhanam, Kamalanabhan, Dyaram, \& Ziegler, 2017; DiPietro \& Condly, 200; Guthrie, 2001; Huselid, 1995; Koys, 2001; Kuria, Alice \& Wanderi, 2012; Pare \& Tremblay, 2007; Pizam\& Thornburg, 2000) and staff shortages (Brien, Thomas, \& Brown, 2017; Davidson, Guilding \& Timo, 2006). Additionally, a combination of other human-related issues could be recognized, for illustration, the difficulty of pulling in and holding staff, managing an assorted workforce, low distinction and status of hospitality employments, maturing populace and drawback of more seasoned workers, the ought to prepare employees in modern communication and information technologies, HIV/AIDS issues, business law, minimum compensation and prohibitive government policies (Kusluvan, Ilhan, \&Buyruk, 2010). Furthermore, employee turnover intention can come out due to a few other variables within the hotel industry such as work environment, work atmosphere, relationship with co-workers, and workplace happiness (Huang \& Zhang, 2019: Stewart, 2018). Hence, the work environment could be a conceivable factor that can lead to staff engagement or turnover intention (Ariza-Montes, Arjona-Fuentes, Han, \& Law, 2018). Hence, this study will try to distinguish the relationship between selective staffing and employee turnover and centring on the mediating role of the work environment.

\section{Employee turnover issues in Malaysian hotel Industry}

Turnover is an endemic issue within the hospitality industry all over throughout the world (Chahal \& Poonam, 2017; Cronin, 2019: Mastar, Darus, \& Shamsudin, 2016). It is indeed concurred within the literature to depict the hospitality culture as a turnover and burnout culture (Kar \&Uysal, 2018; Hemdi \& Rahman, 2010). The turnover rate within the inn industry is evaluated from $60 \%$ to $300 \%$ around the world in comparison with the manufacturing business where the turnover rate is $34 \%$ (Walker \& Mill operator, 2010). In like manner, in Malaysia, the Malaysian Employers Federation (2011) revealed that the turnover rate within the hotel industry is 65.7\% (Zainol, Ahmad Rozali, Nordin, Tazijan, \& Ab Rashid, 2015). 
In Malaysia, turnover is not kept to the operational workers; it stretches out too to the authoritative levels (Zainol et al., 2015). Turnover within the Malaysian hotel industry could be a major issue inferable to the significant reliance of hotels on the human factor. Also, the financial losses and good impacts of turnover on hotels cannot be ignored (Hemdi\& Rahman, 2010; Albattat \& MatSom, 2013).

In Malaysia, various studies have concentrated on employee turnover intention (Nor, Nor, Ahmad, Khalid, \& Ibrahim, 2017; Hemdi\&Nasurdin, 2006; Rahim, 2011). Malaysian considers have found that respondents with the high aim to leave are the people who require transient business were influenced by others to explore for work within the industry and are more arranged towards peer group friendship as contradicted to the specific work (Nor et al., 2017). Human resource practices (Miah \& Hafid, 2019; Hemdi \& Nasurdin, 2006), procedural and distributive justice (Hemdi \& Nasurdin, 2008), organizational citizenship behaviour (Hemdi \& Nasurdin, 2007) and a psychological contract (Rahim, 2011) contribute to reducing turnover intention.

\section{Literature review}

\subsection{Selective Staffing and Employee Turnover}

Selective staffing is the process toward enlisting qualified candidates in the organization or company for unequivocal positions (Bashir,Tufail \& Mahesar, 2018).Within the management, the significance of selective staffing is an operation of enlisting the employees by interviewing their capacities, knowledge and afterwards expanding to them explicit business opportunity specific jobs suitably (Bashir et al., 2018). According to Mastar, Darus, and Shamsudin, (2016) selective staffing can be assembled around issues of high employee turnover, inconvenience in pulling in and holding skilled workers, staff insufficiencies, and destitute control and work commitment. Among these issues, employee turnover has all the earmarks of being the foremost challenging (Betts, 2020). Empirical studies, for the case, those driven by Shaw et al. (1998) illustrate that involuntary turnover is impacted by staffing practices (Abo-Murad \& Abdullah, 2019). Moreover, Schmidt and Seeker (1983) contend that the consideration organizations pay their employee determination impacts the nature of those enrolled. This can be reflected within the staffing strategy - the selection ratio (that is how selective the organization can be) and the legitimacy of the selection process. Utilizing selection methods is likely going to bring almost better-educated enrollment and selection inciting lower involuntary turnover. Huselid (1995) illustrated that selective staffing practices are recognized with supreme turnover. Over the best turnover including imperative staff individuals upsets and anticipates the reasonability of an organization (O'Connell \& Kung, 2007).). Diminishing turnover is noteworthy since it reduces enrollment, selection and training costs, and moves forward the nature of service conveyed (O'Connell et al., 2007).

Different common guidelines for hospitality human resources managers are available to address these staffing in issues (Kusluvan et al., 2010; Nankervis, 2000) and speak to "HR best practice" (Cho, Woods, Jang \&Erdem, 2006). These incorporate selective staffing (Cho et al., 2006; Kusluvan et al., 2010; Nankervis, 2000). Selective staffing is significant to upgrade employee commitment and relieve employee turnover because it applies a strong impact on an organization's way of life (McGunnigle \& Jameson, 2000).Selective staffing implies pulling insufficient candidates to ensure qualified candidates are among them (Millmore, 2003). A sensible job see permits contender to assess the organization reasonably and to select whether they are suitable for the organization (Millmore, 2003; Raub and Streit, 2006). Selective staffing moreover incorporates the utilization of different dependable choice strategies and counting various stakeholders in decision- making (Millmore, 2003).

\subsection{Work Environment and Employee Turnover}

Work environment may have distinctive positive and negative impacts on employees' outcomes, for example, turnover intentions. Meirina, Ferdian, Pasaribu, and Suyuthie (2018) has demonstrated that work environment emphatically impacts on employee turnover intention of 4-star Hotels in Padang City with a relapse coefficient of 0.744 , this suggests in case there is an extension within the estimation of the work environment by one unit it will make strides employee turnover by 0.744 units and vice versa. Arnoux-Nicolas, Sovet, Lhotellier, Di Fabio, and Bernaud (2016) has assessed that extended degrees of unfavourable working conditions would incite extended degrees of turnover intentions. However, diverse research on the distinctive working samples has illustrated that clear work environment may impact turnover intentions (Qureshi, Iftikhar, Abbas, Hassan, Khan, \& Zaman, 2013). Mueller and Cost (1990) have established that the determinants of involuntary turnover are of a psychological, sociological, and economic nature. Their explanatory show of intentional turnover coordinates different sorts of determinants, for a case, working conditions, environmental conditions, and worker characteristics (Qureshi et al., 2013). The authors point out that if employees' wants toward the organization are not fulfilled, the consequences for work satisfaction and to work bring almost the employees deciding to take off the organization.

In this respect, and Lofquist (1984) contends in their show that the level of fulfilment from the perspective of the employee fair as of the employer predicts the degree to which the person is likely reaching to stay. 
In case there ought to emerge an event of a perplex between the person and the working environment, this show predicts sorts of changes between the two. Along these lines, energetic change with regard to the person induces that the individual in the address is endeavouring to alter the working environment $(\mathrm{Ng}$, Hong, Woo, Lim, \& Wong, 2019). Adjusting responsively, individuals may moreover alter their conduct to all the more likely coordinate environment. At the point when no more noteworthy alter illustrates conceivable, the person clears out the work (Ng et al, 2019). As demonstrated by Yu, Liu \& Ren (2019) clarifies the withdrawal strategy, intellectual conduct components are mediators of the relationship among fulfilment and employee turnover. This connected show portrays the subjective strategy in which work dissatisfaction drives the individual, from the start, to consider taking off, and afterwards to arrange to take off, which is joined by the energetic journey for another work, bringing about the selection to take off if a captivating business offered develops.

\subsection{Proposed conceptual framework}

Based on the literature reviewed the theoretical framework shown in figure 1 is proposed:

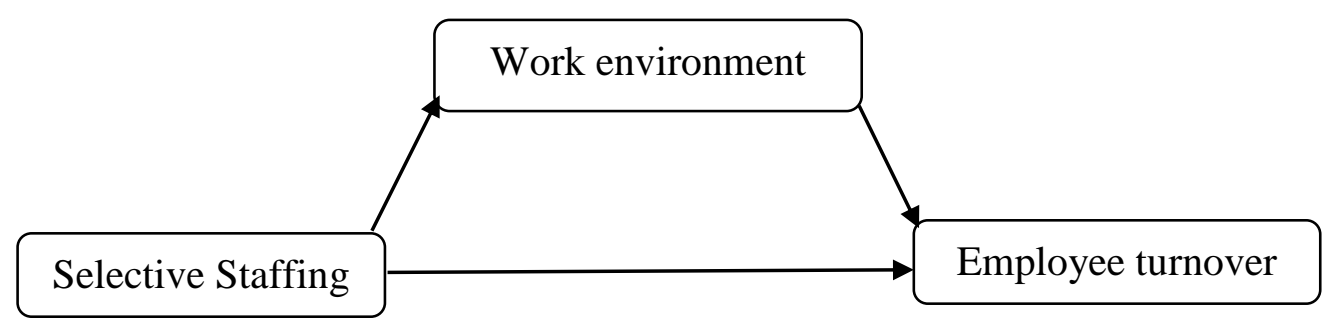

Figure 1: Proposed theoretical framework for predicting relationship between selective staffing, work environment and employee turnover.

Hypothesis 1: There is a positive relationship between selective staffing and employee turnover intention. Hypothesis 2: There is a positive relationship between work environment and employee turnover intention. Hypothesis 3: Work environment mediate the relationship between staffing and employee turnover intention

\subsection{Social Exchange Theory (SET)}

Social exchange theory talks about social relations were counting on the interaction between two parties about cost and benefit analysis (Blau, 1964; Yu \& Tsung-Lin, 2020). By the theory (Blau, 1964) appears that social relations can influence worker demeanour in their work or errand they are proceeding on because past research has shown that high-quality social exchange relationships can determinedly affect charming worker behaviours and attitudes (Rhoades and Eisenberger, 2002; Wayne, Shore, \& Liden, 1997). Employees who have a high-quality exchange relationship with the organization may take an interest in behaviours that are likely attending to be supportive of the organization (e.g., Rhoades \& Eisenberger, 2002).

For particular, within the organization level when employees realize that the organization is taking after the selective staffing process, whereas it wasthe ability and appropriate individual is getting enlist compare to need of appropriate staffing prepare which makes other employees think almost reasonableness and motived, engage them with the organization (Aguenza \& Som, 2012). Other than that, whereas the work environment is supportive, inviting and employee centre that straightforwardly motivates and engage workers to create long term relationship with organizations compare to take off or work searching (Thakur, Ansari, \& Bidkar, 2020). Hence, the over contentions appear that selective staffing from the bosses can alter the state of mind and behaviour of the workers that can lead worker engagement or intention to leave (Aguenza et al., 2012). On the other hand, the work environment is related to lots of variables it can be work conditions, co-worker relationships, working climate, regardless, when employees work environment is favourable to them it makes a difference worker engage with organizations compare to leaving (Thakur et al., 2020)

\subsection{Conclusion}

This study shows that selective staffing can diminish employee turnover and reducing the cost of the organization. Moreover, research also recognized the different components that can create employee engagement with an organization compared to the deliberate of taking off. 
This research also recommends based on the past study that behavioural screening tests amid the interviewing process can lead to less turnover once the candidate becomes employees in a specific organization. Moreover, this study is come up with insights to view the genuine circumstance within the hotel industry within the globe and Malaysia where the most hotel industry is confronting staffing issues and employee turnover (Sangaran\&Jeetesh, 2015; AlBattat \& Som, 2013)

In expansion, this study also shows that the work environment plays a critical effect on employee turnover in any case work environment related to employees' positive or negative attitude approximately their work and organization itself. One of the noteworthy commitments to the body of knowledge it appears the genuine circumstance on the hotel industry in Malaysia point of view and appears the relationship between three variables such as selective staffing, work environment and employee turnover. Another contribution of this study proposes that the work environment mediates in the relationship between selective staffing and employee turnover. The practical contribution of this study appears the way the hotel managers concern around selective staffing and lessening the turnover intention among employees which is exceptionally much exorbitant for the organization itself.

Other than that, this study shows the related factors that can lead an employee's engagement or intention to leave. In a nutshell, it also shows the work environment plays a significant role in employee turnover that needs to concern by the superior manager of the organization. Moreover, this study is not out of limitation, consequently, in this study objective not yet tested. Also, this study focuses on for-profit organization particularly the hotel industry. In this manner, the recommendation to assist further research is centring on other sector compare to the hotel industry and examines the objectives.

\section{Acknowledgement}

This research is supported by Institut Pengajian Siswazah (IPSis), UiTM Shah Alam Campus. Besides, I grateful to Dr Nor Intan Adha Hafit as my main supervisor for her tremendous contribution and guidance to complete this research successfully.

\subsection{References}

Al Mamun, C. A., \& Hasan, M. N. (2017). Factors affecting employee turnover and sound retention strategies in business organization: a conceptual view. Problems and Perspectives in Management, (15, Iss. 1), 63-71.

Ariza-Montes, A., Arjona-Fuentes, J. M., Han, H., \& Law, R. (2018). Work environment and well-being of different occupational groups in hospitality: Job Demand-Control-Support model. International Journal of Hospitality Management, 73, 1-11.

AlBattat, A. R. S., \&Som, A. P. M. (2013). Employee dissatisfaction and turnover crises in the Malaysian hospitality industry. International Journal of Business and Management, 8(5), 62.

Abo-Murad, M., \& Abdullah, A. K. (2019). Turnover Culture and Crisis Management: Insights from Malaysian Hotel Industry. Academy of Strategic Management Journal.

Arnoux-Nicolas, C., Sovet, L., Lhotellier, L., Di Fabio, A., \&Bernaud, J. L. (2016). Perceived work conditions and turnover intentions: The mediating role of meaning of work. Frontiers in psychology, 7, 704.

Aguenza, B. B., \&Som, A. P. M. (2012). Motivational factors of employee retention and engagement in organizations. International journal of advances in management and economics, 1(6), 88-95.

Betts, B. S. H. (2020). The Importance of Human Resource Management in the Hotel industry in Sierra Leone. American Scientific Research Journal for Engineering, Technology, and Sciences (ASRJETS), 64(1), 96-108.

Brien, A., Thomas, N. J., \& Brown, E. A. (2017). How hotel employee job-identity impacts the hotel industry: The uncomfortable truth. Journal of Hospitality and Tourism Management, 31, 235-243.

Bashir, M., Tufail, M. S., \&Mahesar, H. A. (2018). High Performance Work System and Women Employee Attitudes: A Female Worker's Perspective. The Women-Annual Research Journal of Gender Studies, 10(10).

Blau, P. M. (1964). Social exchange theory. Retrieved September, 3(2007), 62.

Chahal, H. S., \& Poonam. (2017). Study of organizational culture, employee turnover and employees' retention in hospitality sector. Pacific Business Review International, 9(11), 119-125.

Cronin, S. (2019). An Investigation into High Labour Turnover and Retention of Front-Line Employees in The Hospitality Sector in Ireland with a Particular Emphasis on a Fun Work Culture (Doctoral dissertation, Dublin, National College of Ireland).

Cho, S., Woods, R. H., Jang, S. S., \&Erdem, M. (2006). Measuring the impact of human resource management practices on hospitality firms' performances. International Journal of Hospitality Management, 25(2), 262-277.

DiPietro, R. B., \&Condly, S. J. (2007). Employee turnover in the hospitality industry: An analysis based on the CANE model of motivation. Journal of Human Resources in Hospitality \& Tourism, 6(1), 1-22. 
Davidson, M., Guilding, C., \& Timo, N. (2006). Employment, flexibility and labour market practices of domestic and MNC chain luxury hotels in Australia: Where has accountability gone? International Journal of Hospitality Management, 25(2), 193-210.

Deery, M. A., \& Shaw, R. N. (1997). An exploratory analysis of turnover culture in the hotel industry in Australia. International Journal of Hospitality Management, 16(4), 375-392.

Dawis, R. V., \&Lofquist, L. H. (1984). A psychological theory of work adjustment: An individual-differences model and its applications. University of Minnesota press.

Federation, M. E. (2011). The MEF salary and fringe benefits survey for executives in 2010 and 2011. Kuala Lumpur: Author.

Guthrie, J. P. (2001). High-involvement work practices, turnover, and productivity: Evidence from New Zealand. Academy of management Journal, 44(1), 180-190.

Haynes, N., \& Egan, D. (2020). The perceptions of frontline employees towards hotel overbooking practices: exploring ethical challenges. Journal of Revenue and Pricing Management, 1-10.

Huselid, M. A. (1995). The impact of human resource management practices on turnover, productivity, and corporate financial performance. Academy of management journal, 38(3), 635-672.

Huang, C., Wu, K., \& Zhang, Y. (2019). Understanding precedents for frontline employee turnover in luxury hotels: Emotional intelligence as a unifying factor. Journal of Human Resources in Hospitality \& Tourism, 18(1), 26-46.

Hemdi, M. A., \& Rahman, N. A. (2010). Turnover of hotel managers: Addressing the effect of psychological contract and affective commitment. World Applied Sciences Journal, 10(Special Issue Tourism \& Hospitality).

Hemdi, M. A., \&Nasurdin, A. M. (2006). Predicting turnover intentions of hotel employees: The influence of employee development human resource management practices and trust in organization. Gadjah Mada International Journal of Business, 8(1), 21-42.

Zainol, N., Ahmad Rozali, A., Nordin, N., Tazijan, F., \& Ab Rashid, P. (2015). Employees dissastification and turnover crises: A study of hotel industry, Malaysia. Nakia and Tazijan, Farina and Ab Rashid, Putri, Employees Dissastification and Turnover Crises: A Study of Hotel Industry, Malaysia (March 11, 2015).

Kusluvan, S., Kusluvan, Z., Ilhan, I., \&Buyruk, L. (2010). The human dimension: A review of human resources management issues in the tourism and hospitality industry. Cornell Hospitality Quarterly, 51(2), 171-214.

Koys, D. J. (2001). The effects of employee satisfaction, organizational citizenship behavior, and turnover on organizational effectiveness: A unit- level, longitudinal study. Personnel psychology, 54(1), 101-114.

Kuria, S., Alice, O., \&Wanderi, P. M. (2012). Assessment of causes of labour turnover in three and five star-rated hotels in Kenya. International journal of business and social science, 3(15).

Kara, D., \&Uysal, M. (2018). Gender differences in burnout perceptions: the case of hotel employees. In Handbook of Human Resource Management in the Tourism and Hospitality Industries. Edward Elgar Publishing.

Marsden, P. V. (2017). Interpersonal ties, social capital, and employer staffing practices. In Social capital (pp. 105125). Routledge.

Mastar, C. N. C., Darus, A., \&Shamsudin, A. S. (2016). Relationship Between Perceived Organizational Politics and Turnover Intention of Hotel Industry in Malaysia. The Social Sciences, 11(30), 7195-7198.

Miah, M., \&Hafid, N. (2019). A Review Study of the Human Resource Management Practices on Job Satisfaction of Hotel Industry Employees of Malaysia. International Journal of Human Resource Studies, 9(3), 75-85.

McGunnigle, P. J., \& Jameson, S. M. (2000). HRM in UK hotels: a focus on commitment. Employee Relations.

Millmore, M. (2003). Just how extensive is the practice of strategic recruitment and selection? Irish Journal of Management, 24, 87-108.

Meirina, I., Ferdian, F., Pasaribu, H. S., \&Suyuthie, H. (2018). The influence of work environment towards turnover intention of employee of 4 Star hotels in Padang City. Journal of Business on Hospitality and Tourism, 4(2), 97-104.

Mueller, C. W., \& Price, J. L. (1990). Economic, psychological, and sociological determinants of voluntary turnover. Journal of behavioral economics, 19(3), 321-335.

Naik, N. K. K., \&Kanade, S. R. (2019). HRM in hospitality industry: an overview. Advance and Innovative Research, 136.

Nor, M. N. M., Nor, A. N. M., Ahmad, Z., Khalid, S. A., \& Ibrahim, I. I. (2017). Factors affecting turnover intention among gen $\mathrm{Y}$ in hotel industry. JurnalIntelek, 12(1).

Nasurdin, A. M., Hemdi, M. A., \&Guat, L. P. (2008). Does perceived organizational support mediate the relationship between human resource management practices and organizational commitment? Asian Academy of Management Journal of Accounting and Finance, 13(1), 15-36.

Nankervis, A. R. (2000). Human resource management strategies as competitive advantage: A case example of the hospitality sector in Southeast Asia \& the Pacific Rim. Research and Practice in Human Resource Management, 8(1), 111-133. 
Ng, A., Hong, H., Woo, W. N., Lim, K. Y., \& Wong, C. H. (2019). Factors affecting the Staff Turnover Intention: A Case study of a Malaysian Steel Manufacturing Company. INTI JOURNAL, 2019(42).

O'Connell, M., \& Kung, M. C. (2007). The Cost of Employee Turnover. Industrial Management, 49(1).

Paré, G., \& Tremblay, M. (2007). The influence of high-involvement human resources practices, procedural justice, organizational commitment, and citizenship behaviors on information technology professionals' turnover intentions. Group \& Organization Management, 32(3), 326-357.

Pizam, A., \& Thornburg, S. W. (2000). Absenteeism and voluntary turnover in Central Florida hotels: a pilot study. International Journal of Hospitality Management, 19(2), 211-217.

Qureshi, M. I., Iftikhar, M., Abbas, S. G., Hassan, U., Khan, K., \& Zaman, K. (2013). Relationship between job stress, workload, environment and employees' turnover intentions: What we know, what should we know. World Applied Sciences Journal, 23(6), 764-770.

Rahim, A. R. A. (2011). The effect of psychological contract and affective commitment on turnover intentions of hotel managers. International Journal of Business and Social Science, 2(23), 76-88.

Raub, S., \&Streit, E. M. (2006). Realistic recruitment. International Journal of Contemporary Hospitality Management.

Rhoades, L., \& Eisenberger, R. (2002). Perceived organizational support: a review of the literature. Journal of applied psychology, 87(4), 698.

Stewart, A. (2018). An Analysis of the Factors Affecting Employee Retention and Employee Turnover in the British Hospitality Industry (Doctoral dissertation).

Santhanam, N., Kamalanabhan, T. J., Dyaram, L., \& Ziegler, H. (2017). Impact of human resource management practices on employee turnover intentions. Journal of Indian Business Research.

Sangaran, G., \&Jeetesh, K. (2015). The effects of job satisfaction towards employee turnover in the hotel industry: A case study of hotels in Kuala Lumpur City Center. J Tourism Hospit, 4(142), 2167-0269.

Tuan, L. T. (2018). Driving employees to serve customers beyond their roles in the Vietnamese hospitality industry: The roles of paternalistic leadership and discretionary HR practices. Tourism Management, 69, 132-144.

Thakur, M. B., Ansari, S., \&Bidkar, P. (2020). Exploring the relationship between Work Environment and Job Satisfaction. Our Heritage, 68(1), 943-956.

Wayne, S. J., Shore, L. M., Bommer, W. H., \&Tetrick, L. E. (2002). The role of fair treatment and rewards in perceptions of organizational support and leader-member exchange. Journal of applied psychology, 87(3), 590.Yu, S., Liu, C. E., \& Ren, H. Y. X. Y. J. (2019). Work-Related Identity Discrepancy and Employee Turnover Intention: The Mediation Effect of Job Satisfaction. International Journal of Business and Social Science, 10(11).

Yu, O., \& Tsung-Lin, L. (2020). A study on local identity of low carbon tourism based on social exchange theory-a case study of Taiwan's characteristic hot spring area. International Journal of Organizational Innovation (Online), 12(3), 355-366.

Xiong, R., \& Wen, Y. (2020). Employees' turnover intention and behavioral outcomes: The role of work engagement. Social Behavior\& Personality: an international journal, 48(1). 